\title{
GLOBAL VIEW OF THE MAIN REASONS TERRORISM EMERGENCE
}

\author{
Sarteep Mawlood ${ }^{l}$ \\ ${ }^{1}$ Postgraduate student, «KROK» University, Kyiv, Ukraine, e-mail: sarteep30@gmail.com, ORCID: \\ https://orcid.org/0000-0002-0663-208X
}

\begin{abstract}
Whereas global lives under globalization system, many things became easy to be available for normal and non-extremist people meanwhile the same thing is true for the extremist and terror groups. When resources become more then the reasons become more and diverse as well especially when the subjects are about human rights, deprivation of basic services such as speaking in their mother tongue, perform religious rituals, living in very hard situation and poverty, lack of having enough teaching centers, schools, medical centers. In another hand using violence, planting hating and enmity among people by using media, technology, fliers or any other means which motivate extremist, terror, attract other feeling, is another problem nowadays. The article aims to know the main and maximum reasons, root causes of violence, extremist and terror, study every single situation a lone, what are motivations behind them, what can we do understand the situation better, diagnose the problem, what is the best way for solving the issue, how the procedures will be, what we can do in case if we could not reach to the right point in future, how we can distinguish cases from time to time and from place to place according to its case and situation, how to lessen hating, violence, and several other issues that mentioned during the article. Based on it, the article contains several researches, studying, diverse other articles meanwhile different ways and methods are used to have maximum information about the issue in different lines and corners, which can be useful for further researchers or study.
\end{abstract}

Keywords: terror, violence, radical, extremists, terrorism determinants, media, economic, political system, discrimination, counter terrorism plans, reasons

JEL Classification: K4, K10, K11, K14, K24, K41, K42

Formulas: 0; fig.: 1; tabl.: 0; bibl.: 11.

Introduction: Although international communities are considered terrorism the most dangerous act in both national and international levels, tried to face the challenge, eliminate and tackle it all together but they did not pay too much attention to factors behind those acts which might be different from place to another and time to time. These reasons are still the major challenges before states, communities, meanwhile, the role of UN, international organizations and other legal institutions are weak or not at the required level.

Literature Review: Various international views on the reasons behind terrorism are reviewed independently in the article due tremendous difference global views on terrorism acts and deal with. In this study they will be analyzed and compared against one another to analyze the differences and similarities in how the countries, UN member states, other entities is treated with terrorism according to their views.

Aims: The goal of the study is to outline and analyse views on the appearance of terrorism within various international organization, states, communities in order to know the real and fact reasons behind terrorism on the ground and then work with it properly.

Methods: Methodology of the study based on theoretical basis and other methods are used such as gathering ideas, analytical, synthesize the elements of the different studies, the logical structures as well as the comparative studies. 
Results: Throughout the history the worldwide has been seen different levels of terrorism acts, in term of strategy some academics identified the concept as "Waves of Terrorism" which can arise and fall in different times and places. The wave theory further reflects that terrorist groups can dissolve when no longer capable of inspiring others to continue with violent acts. This point also suggests that terrorism and its motivations are clearly impacted by the conditions of and changes in social and political cultures. In contrast, others posit that violent terrorist situations occur around the world not so much in waves, but because terrorist actors are motivated by different goals such as socialism, nationalism, religious, extremism, exclusionism and others. These underlying motivators are not chronologically sequential and do not agree with one strain dies and a new one arises. Instead, they can work in parallel, and can occasionally overlap, to motivate different terrorist movements according to their needs [1].

Most definitions of terrorism recognize that terrorists don't just pursue violence for the sake of it but have a specific purpose and it could be social and political injustice, religious beliefs, ideological beliefs, socio-economic factors or anything else which be different by groups to others meanwhile from place and time to another. Individuals or groups may use terrorism because they don't agree with the current situation of society and they want to change it. They may believe that violence, or the threat of violence, will coerce society or other parties into making a change or accept the change when happens. Throughout history many terrorists have stated that they turned to violence after long deliberation, because they felt they had no other choice [2].

Others see reasons for terrorism are an example of the so-called system of communicating vessels. This means that they are a sum total of a plethora of different elements, their mutual relations and the conditions that influence them. Therefore, they are $\leftarrow 49 \mid 50 \rightarrow$ a "system" coupled with other elements of terrorism such as tactics, strategies, or the consequences of terrorist activities. One can divide them into simple and complex ones if we attempt to classify the reasons of terrorism. The simple group characterized and defined motive predominates or the so-called antiabortion terrorism. The latter group involves complex reasons, where various motives, e.g. religious, ethnic, political, overlap. This applies to a majority of cases of terrorism. In the opinion of A. Cronin, all reasons for terrorism can be divided into four levels. The first one is the individual level which is provided by external factors that lead an individual to become involved in terrorist activities, and the personal traits specify involvement more or less likely. The second level is of organizational nature, related to a group dynamics and the issues of group identification. Shared ideology, belief systems, and the activities of a given group are of key significance. Feeling of injustice and harm is one of the strongest psychological conditions to the first and second levels. The third level is related to the activities of the state and the need to analyze the different ways in which states take advantage of terrorism. The fourth and last one is focused on the international system and $\leftarrow 51 \mid 52 \rightarrow$ refers to Samuel Huntington's theory of the clash of civilizations, or the transformations that accompany globalization, secularization, etc. [3]. Terrorism continued to spread to 
more violent acts in more countries as much as possible. Terrorism is largely centralized in the Middle East and North Africa (MENA), South Asia and subSaharan Africa regions, The countries located are most impacted by terrorism which together account for 84 per cent of attacks and 95 per cent of deaths.

Different levels of foundations, organizations, entities including public and private sectors are targeted by terrorism which some of acts done by ethnic militants and groups of semi-nomadic. The majority of deaths in some countries are classified as a result of warfare among ethnics, nationalities, religious, and other groups rather than acts of terrorism. However, terrorism has been deployed as a tactic by some of the rebel forces.

Many of the countries previously suffering from moderate levels of terrorist activity. There were improvements in countries with very low levels of terrorism. There are divergent trends for countries that experienced terrorist activity that if they giving more freedom violent acts will decrease [4].

The rise in terrorism in these countries is reflective of a global trend, some of these countries were involved in internal conflict, which has facilitated and led to an increase in terrorism. With the exception of these countries which have terrorist groups that are responsible for the majority of deaths. However, other countries have been impacted by events which have led to the rise of terrorist groups and make instability in security, social, economic, political as well as several crises, that's why more countries are experiencing moderate to high levels of terrorism. In other countries terrorism has followed the destabilization of the government, while in others terrorism has resulted from a foreign power invasion. There are regional variations in terms of who is attacked and the methods used however in all regions civilians are frequently targeted more than others. There are regional variations in terms of economic-political or other interests, countries use methods of aggressive pressure and intimidation against each other and then it leads to create terrorism and extremist groups and however in all regions civilians are frequently targeted more than others. Terrorism is linked to the instability of the internal and international levels, this rapid deterioration of instability highlights the creation of terrorism [5].

The political change may create political vacuums which terrorist groups use to push their agendas. Such vacuums are attractive as radical groups are less likely to be challenged by an instable, thus weak government Also, an individual may find it more attractive to join or support a radical organization because there are few nonviolent alternatives. Instable or failed states may even serve as schools of international terrorism, where in phases of domestic instability individuals gain an 'education' in violence that they can also use for internationalized terrorist campaigns . Several studies find that more liberal and democratic countries are significantly less likely to produce transnational terrorism. That's why unveiling the causes of terrorism and deriving sound policy advice is important so as to know where is the problem and how can we deal with it. [6] Many terrorisms exist, and their character has changed over time and from country to country. The endeavor to find a "general theory" of terrorism, one overall explanation of its roots, is a futile and misguided enterprise. Terrorism has changed over time and so have the terrorists, their motives, 
and the causes of terrorism. Psychiatrist Jerrold Post makes that caveat even more directly applicable to an exploration of the psychological dimension of terrorism. He cautions that "there is a broad spectrum of terrorist groups and organizations, each of which has a different psychology, motivation and decision making structure.

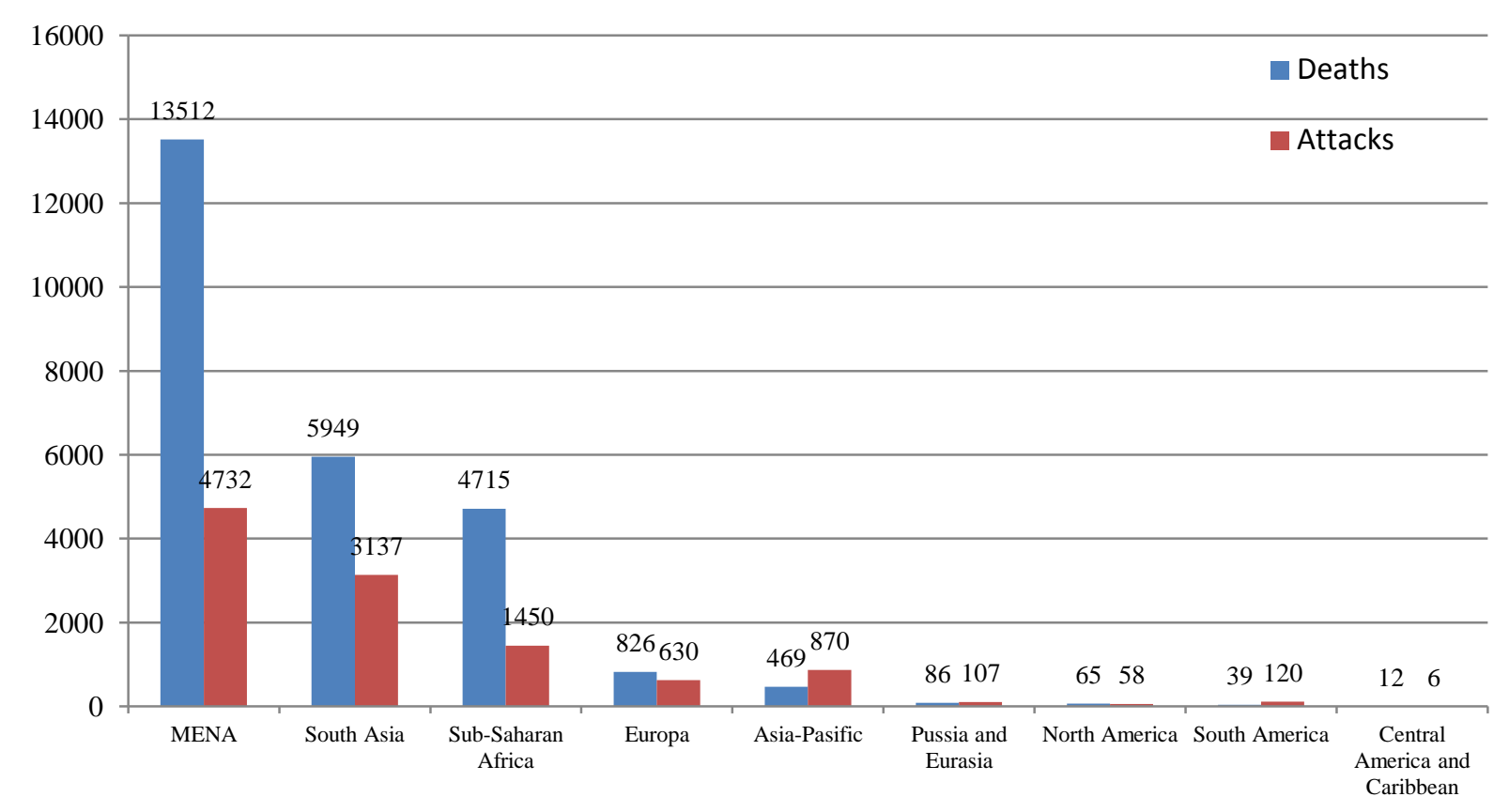

Fig. 1. Number of deaths and attacks by terrorism in 2016 by region, Source:_global terrorism index-vision of humanity,_2017 [5]

Indeed, one should not speak of terrorist psychology in the singular, but rather of terrorist psychologies. General observation is that most violence can be usefully viewed as intentional. It is chosen as a strategy of action. It is purposeful (goaldirected) and intended to achieve some valued outcome for the actor. It is not the product of innate, nor is it the inevitable consequence of predetermining psychological and social forces. Obviously, many factors influence that decision and the competing options available, but humans typically are not passive vessels for involuntary displays of behavior. Certainly, there are exceptions. One can conceive of circumstances where an individual might have some brain dysfunction that causes general disinhibition and/or emotional instability that may result in aggression or violence. This would be inconsistent, though, with the kind of organization and planning necessary to carry out a terrorist attack. In reviewing explanatory theories and empirical models, it is perhaps not surprising to learn that the discipline of psychology has yet to develop or discover (much less agree upon) any that substantially explain violent behavior, particularly across its many contexts, motivations and actors.

The problem is not that researchers, scholars and practitioners have not tried to locate such an explanation, but the "holy grail" has proved to be elusive. In fact, it is probably fair to say that psychological theoretical development in explaining violence has been given less attention, and has made less progress than in many behavioral realms of substantially lesser social importance or consequence. Social scientists who 
seek to understand terrorism should take account of the possibility that biological or physiological variables may play a role in bringing an individual to the point of performing an act of terrorism [7].

Previous research suggests that multiple variables cause terrorism. Most likely, many circumstances converge to create the conditions for terrorism and the chances of terrorism taking place increase dramatically. There are different forms of terrorism, and each form has its own causes. Terrorism happens in both poor and rich countries, and regardless of the type of government. What is most likely is that any certain form of terrorism is the result of a combination of factors. Including political and economic modernization, deprivation, and class structure. The term used by the political science community to refer to these variables are "root causes", either direct or indirect factors that help us understand various incidents of terrorism. There are main causes which contribute to the violence and terrorism such as problem with the poverty variable is that is can encompass a large variety of other smaller variables that all contribute to what can define someone as being impoverished.

In the Middle East, many societies have great potential yet there are many citizens left without jobs and this causes a lower standing of living. When social inequality develops, many people become angry because they are unable to achieve what others are easily able to, thus creating internal conflict within certain geographic areas, and making it more likely for terrorism to occur as a result. One study found that lack of economic opportunities and economies with slow growth had strong ties with numerous terrorist activities, meanwhile interesting theory is that natural disasters create opportunities for terrorism.

However, this is another variation of the poverty theory, and some researchers argue that natural disasters create strain and hardship within societies. In addition an alternative theory says that political factors like government repression leads to terrorism. Examples of variables used to measure government repression are political rights and civil liberties. Unstable, and according to some, undemocratic societies form weak governments causing the people to suffer. Human rights abuses would also fall into this category since this is a direct result of government action, and would then be considered a form of repression. Human rights violations, including dispossession and humiliation, result in people having severe grievances against the government. Certain studies show that terrorism has a strong link with social injustice at the hands of the government rather than poverty. When the government is unable to provide basic standard of living, citizens become displeased and this is when terrorist organizations are able to recruit. It is up to the government to provide the resources necessary for the people to survive. This includes hospitals, medical care, jobs and schooling. Many believe it is the job of the government to provide political freedom to their citizens. Some other possible variables may be related to social issues. Levels of education have been mentioned in a few different studies, but there has not been much evidence to validate it as an important variable. However, it is still a good indicator of a social issue within a country and is therefore worth testing in my study. 
The Human Development Index includes per capita income, life expectancy, and education into account in regards to terrorism, and found that there is a correlation between terrorism and human development. Religion is another social aspect that needs to be considered. Modern terrorism has seen an enormous increase in religious extremism, the scale of violence has intensified, and the global reach has expanded. Religious terrorism can be defined as political violence that is motivated by an absolute belief that another-worldly power has sanctioned, or sometimes commanded, terrorist violence for the greater glory of the faith. People who partake in religious terrorism believe that any acts they commit will be forgiven and perhaps rewarded in the afterlife [8].

Radicalism more accurately reflects the political and ideological dimension of the threat. No matter how diverse the causes, motivations, and ideologies behind terrorism, all attempts at premeditated violence against civilians share the traits of violent radicalism. While terrorism is a deadly security challenge, radicalism is primarily a political threat against which non-coercive measures should be given a chance. There is nothing preordained in the possible transition from radicalism to terrorism. All terrorists, by definition, are radicals. Yet all radicals do not end up as terrorists. In fact, only a few radicals venture into terrorism. At the same time, it is clear that most terrorists start their individual journey towards extremist violence first by becoming radicalized militants. Since radicalism is often a precursor to terrorism, focusing on radicalism amounts to preventing terrorism at an earlier stage, before it is too late for non-coercive measures. Finally, radicalism, unlike terrorism, has social dimensions.

There are radicalized societies where acts of terrorism find some sympathy and degree of support. It is impossible to talk about terrorism as a social phenomenon, however. There are no 'terrorist' societies. This is why focusing on the collective grievances behind radicalism is probably the most effective way of addressing the root causes of terrorism. This effort at prevention can be conceived of as a first line of defense against terrorism. The goal is to reduce the social, economic, and political appeal of terrorism by isolating terrorists and winning over potential recruits. Once the challenge is defined as such, the next and more difficult step is to identify an effective strategy to fight radicalism. Breeding grounds for radicalism and terrorist recruitment emerge not necessarily under conditions of abject poverty and deprivation, but rather when negative social, economic, and political trends converge. In fact, when analyzed in a broader framework of socio-economic and political deprivation, the societal support for terrorism and radicalism gains greater relevance. Dismissing the social and economic causes of radicalism on the grounds that some terrorists have middle-class backgrounds is simplistic and misleading. Weak, failing, and failed states; ungoverned spaces; and civil wars that create safe havens for terrorism are all in underdeveloped parts of the world, not in the industrialized West. Terrorism is not necessarily caused by socioeconomic problems. But there is certainly a correlation between deprivation and radicalism [9].

Today's terrorists are ultimately more apocalyptic in their perspective and methods. For many violent and radical organizations, terror has evolved from being a 
means to an end, to becoming the end in itself. The National Commission on Terrorism quoted R. James Woolsey: “Today's terrorists don't want a seat at the table, they want to destroy the table and everyone sitting at it. Some analysts argue that the evolution of terrorism represents continuity rather than change, which masscasualty bombings have long been characteristic of terrorist methods, and that radical extremism has always dominated terrorist motivations. Most recent scholarship, however, has taken the perspective that contemporary terrorism represents a significant departure from the past.

Various factors have led to the development of this new type of terrorism. Paul Wilkinson pondered the increase in indiscriminateness among terrorists, and he posited several possible reasons accounting for this upsurge. First, the saturation of the media with images of terrorist atrocity has raised the bar on the level of destruction that will attract headline attention. Second, terrorists have realized that civilian soft targets involve lower risk to themselves. Finally, there has been a shift from the politically-minded terrorist to the vengeful and hardline fanatic. While Wilkinson's factors accurately describe developments in terrorist strategy and tactics, there are more fundamental forces at work.

The world has undergone a variety of changes on several levels. While it is impossible to link all social changes to terrorism today, it is possible to track several distinct factors that have converged to evolve a form of terrorism that is unprecedented in the level of threat it poses around the world, which explores these factors from cultural, political, and technological perspectives. At the same time that globalization has provided a motivation for terrorism, it has also facilitated methods for it." In addition to the cultural and religious motivations of terrorists and the political and organizational enabling factors, technology has evolved in ways that provide unprecedented opportunities for terrorists.

However, nonnuclear weapons of mass destruction and information technology also have created opportunities for terrorists that are in many ways more threatening than radiological terrorism because these alternatives are more probable. Some theorists have argued that weapons of mass destruction do not represent a weapon of choice for most terrorists, even in these changing times. Stern writes that "most terrorists will continue to avoid weapons of mass destruction (WMD) for a variety of reasons," preferring the "gun and the bomb". Brian Jenkins agreed that most terrorist organizations are technologically conservative, but he also noted that the selfimposed moral restraints which once governed terrorist actions are fading away. As the trends in the preceding sections reach fullness, increasing the proclivity toward mass-casualty terrorism, terrorists may turn more to these weapons that will better fit their objectives and moralities.

Walter Liqueur's New Terrorism emphasizes the availability of very powerful weapons of mass destruction as the major current danger facing the industrialized world. Aside from the nuclear variety of WMD, biological and chemical weapons pose serious dangers. Biological weapons can come in a variety of forms, including viruses, bacteria, and rickettsia (bacteria that can live inside host cells like viruses). Chemical toxins differ from biological weapons in that they are nonliving pathogens 
and require direct infection and contact with the victim. This negates the continual spread of the weapon, but it entails more direct and possibly more damaging effects. [10]

Modern terrorism is media terrorism. The media are attracted by extreme terrorist acts not only because it is their duty to report on any major event but also because, at the same time, the dramaturgy of terrorism attracts large scale attention. Today's terrorists have picked up this dynamic and take action not only to make their victims suffer but also to create maximum attention around the world. Terrorists have become "media competent" by knowing and applying the principles of attracting media attention in most of their activities. Not only do they now own the necessary technical equipment such as video cameras and Internet facilities, they also usually know how to time and create those images which can guarantee a maximum impact through the media. This dynamic could lead to the conclusion that a major option for the prevention of terrorism would be not to allow journalists and the media to report on terrorist activities or events or at least to inhibit coverage as much as possible. Several countries indeed have chosen this option and it is difficult in those countries to have access to information or events that are related to terrorist activities.

Modern democracy is however characterized to a high extent by its freedom of expression and the possibility to access relevant political or societal information. As soon as information related to terrorism is blocked by governments or other political or societal institutions, terrorists may have gained one of their goals, namely to compromise the values of modern democracy.

Thus, political institutions, as well as the media, are faced with the basic dilemma that on the one hand media coverage may be instrumentalised by terrorists in order to get maximum attention while, on the other hand, if such information is inhibited, the basic principle and value of freedom of expression and information is under threat. Concentrating on the terrorist events themselves and not on the motives when reporting on terrorism may of course limit the number of people who may be called terrorists. Journalists can cover any aspect of political violence including supporters and groups which may be sympathetic with terrorist goals. But it can be dangerous to "over-generalize" the label "terrorist" to include a larger number of people and who may be drawn deeper into terrorist tendencies exactly because they are already labelled as such.

In fact, political integration into the democratic system with convincing means of trust and education may be a more efficient way of preventing a terrorist "periphery" from growing into violence than creation, at an early stage, of a whole out-group of "enemies" by classifying every member of a certain grouping as terrorists without distinguishing between actual attackers and others only loosely linked with these attackers. One should also consider that terrorism may also actually be supported by the fact that "normal" criminal activities when labelled "'terrorism" receive a certain, if negative glorification and attraction for those who appreciate being (anti-) heroes. Many so-called terrorist activities are more based on normal criminal behavior than on political motives. That does not make them better or worse for the victims or the political system but it may create a different context or 
connotation for them in the media and limit the probability that their actions are perceived as being rewarding for a higher, ideological goal. Many, if not most attacks in the context of "terrorism" serve goals other than to reach or realize political objectives. They are about money, attention, status, other advantages, or just about keeping a group alive and intact [11].

Discussion: During the study we found out that some academics see terrorism acts like inheritance which is transmitted from generation to another or from predecessor to successor with little political and cultural influences and it is just a wave that cannot be stopped, linked to each other in a series groups hand over and groups take over but with slight difference in acts. In contrary others see terrorism acts cannot be linked but occur around the world without chronologically sequential but motivated by different achievements might be socialism, nationalism, religious or any other factors who push them to act violently.

Hence, some definitions of terrorism identify that terrorists use violence not for sake of it but for reasons and specific purposes that they fight for, they want to get them in the use of violence, they thing using violence is the way that they can change the situation and nothing else. They believe after waiting for a long time without changing the situations then it's the time to change it by force and exactly in using terror and violence, feel have no other choice. There are different elements, conditions that influence groups, individual to make terrorism and violent acts but these elements, conditions are not enough sometime to get their acts done, related with other elements of terrorism such as tactics, strategies, or the consequences of terrorist activities.

These reasons can be in different kind of levels, might be in individual level which some external factors lead the person to occur terrorism acts, here the personal traits has a big relation to the act which makes involvement more or less likely, or might be in groups and have organization nature, they have same ideology, beliefs because individual, groups feel injustice and harm that's why want to use some kind of violent acts and they see it's a suitable revenge for them. There is also another level that some specific state organization support terrorism groups to make some kind of hostility and enmity against other state, country or society for political, economic and other reasons.

Another level is related to international system which leads to clash of civilizations, or the transformations that accompany globalization, secularization, development in technology, other fields among communities, societies, it is because some cannot accept others and always want to make unfair rival and competition due to several issues such as economic, technology, etc.

The statistics shows us that no country, region or community is far from terrorism but the rate is different from place to another and from time to time which most violent acts occur in those countries where the human rights in general are violated or in minimum level, the highest number of deaths, attacks of terrorism have done in south Asia and sub Saharan Africa where there is discrimination among ethnics, religious, sectarian, and other groups .It is appeared to the world that any kind of reginal and international conflicts create hatred among societies in general 
and increase violence and terrorism in particularly, thus, this conflict is not in the interest of any country or society, and as result it negatively affects the whole world which might be difficult to control it or return to the starting point. It is not fair and true if we say in all situation of changing political system there will be production of terrorist, meanwhile there might be existing of terrorists even in stable and strong states and countries. Besides it depends on the cultural level of the people who live in that country as well as the feeling and sense of responsibility before the state and people, thus both weak and strong governments can attractive terrorists or gathering radical group without changing political system or having political vaccums.

Some researchers, including psychologists believe that psychological factors are primary motivation for perpetrating violence and terrorism in society and then goes from place to another and exploiting them by others in solidarity with other fluctuations and changes such as political system, economic, other circumstances which make the individual to think about violence and hurts others by using terror, killing, kidnapping, hijacking, others, besides they say that who have this issue and then do violence intentionally for some purposes which make them feel well and to have their goals.

According to the researchers there are multiple variables cause violence and terrorism which some of them are root causes and there are other circumstances which facilitate the conditions to create terrorism and make extremist group interested in violence, that any certain form of terrorism is the result of a combination of factors and there is a big relationship between the factors and the act of terrorism. Those factors might be poverty, political, social, religion, violating of basic human rights or any other reasons and factors which contribute to terrorism, all agree the scale of terrorism and violence has increased in both the national and international levels. On the flip side other analyzers see there is certainly a correlation between deprivation and radicalism and radicalism has a big reflects on the violence and terrorism in particular, no matter what are the causes are reasons behind the terrorism act. Facing radicalism and extremist needs non coercive ways because as they see all terrorists are radicalism, but still there are some radicals do not venture to terrorism, there are still chance to bring them back on the right way as the radicalism has a social dimensions, terrorism is not a social phenomenon but also heinous act which hurts all community in general regardless the race, sex, nationality, religion or other backgrounds.

Whereas some authors think terrorists just want to circumvent and exploit time to have developed technologies to strike society, people and have weapons that will better fit their objectives and moralities. New Terrorism tries to have a very strong weapons of mass destruction such as Biological weapons which can come in a variety of forms, including viruses, bacteria, and other forms as well as chemical weapons which already used by some of extremist groups and it is a real dangerous on all human beings on the ground. The technology has developed nowadays and it facilitated extremist groups to have recent nuclear and nonnuclear weapons, so that there is no resistance against them and to repel them they try hardest to have newest methods and technologies. Then again media is used in a large scale by extremist 
groups so their heinous work can be promoted through media such as social media, internet, radio, TV and other means, which leads to intimidate people in the same time attract and gain people`s feeling and attention in some specific cases, so in general media is under threaten and became the most dangerous means to publish violence and terror.

Conclusions. When we talk about terrorism we should analyze reasons of terrorism and what makes terrorism, terrorism acts is not such as inheritance but there are factors which push them to do violent acts and all human being were born equally and without premeditation.it shows that individuals and groups fight for specific purposes and they see that their rights have been taken by others it might be solved if they negotiate in another way. Unfair rival and unjust completions among societies, communities make escalation of terrorism acts, and the injustice and harm by authority, governments other organization make individual, group feel second grade. We see all ethnics, religious, cast, sectarian and other groups are impacted by terrorism and violent acts without any exceptions and terrorism has no specific religious, goals or legitimate rights but they exploit ethnics, religious, sectarian, political and other groups to facilitate their actions and make strife and discord among those various of communities and tells them that authority, government or specific groups do not give your people right to practice your religious ritual, political and social rights.

The instability in security, social, economic, political ....etc. have impact on all countries, communities and it is like environment that effect every place and people, nowadays worldwide became a small and everyone knows about another which if there is no freedom in specific country then will effect another one, and because of needs of life necessary then life has become more difficult nland needs more struggle to live.

In addition another reason of terrorism emergence is the countries themselves which there are countries use some kind of pressure or make some crises in different countries which their political views are not the same or might there are some problems and issues among them in term of economic, borders, financial,... etc. then support some specific ethnic, religious and other groups against each other to force them to accept and subjugate its demand otherwise there will not be instability. Unfortunately that kind of issue is visible nowadays and many states, countries other institutions follow this method in both national and international levels.

All states, entities even political parties have systems which they can go with according to their atmospheres, economic, social relations ...etc. these systems can be changed from place to place or from time to another with according to the adaption of the situation, so why we fear from changing system of the one of these foresaid mentioned? Why we do not fear from changing of technologies, weather, air pollution, suppress freedom, killing innocent people just because of their color, ethnic, languages and religion? Does international community want dictator system? What and how if some political system is toppled in a country for whatever the reason? How if there is transitional government in a state till an elected or legitimate government is formed within standard time? In addition there are other cases might 
be happen, so it is the freedom of people to choose any political system and it does not mean there will be terrorism acts in case if other states do not interfere to that countries, the problem is not with the system or with the changing of political system or having political vacuums but the problem is with the states itself and how harsh the government or the political system was. In general every normal human being is born in a best conditions without any physical or mental problems or handicaps as the God says in holy Qur'an at the verse 4 in Surah (Fig-Tin) "We created man in the best calendar(situations)", except for people who are born with some kind of physical or mental disability from the very beginning of birth, most of them are taking care by their families or specific medical center or therapy which in almost all situations do not use violence acts to terrorize other people, but there are other factors out of the internal control of human being make singular to have mental or psychological problem which might lead to use violence, killing people, terrorize society and it poses dangerous to the individual at first then to the national and international community.

The most important thing is to diagnose the problems before we get ill, because taking care of our society, understanding their problems knowing the issues by the authority before we have such as kind of people which makes us not to control the situation or become so hard and so late. It is something quite odd that still researchers have not found the exact root causes of the terrorism or they have not found the solutions for the root causes in case if they are already found in spite of mentioning many reasons and factors which lead to use violence in general and terror in particular.

On the other hand we see sometimes even the researchers have some kind of partiality to a party against another in field of religion, nationality, racism or any other interests which leads to change the main reasons of the terror, cannot have correct information in the same time accumulation and worsening of the situation from bad to worse without real and fact solutions for the case. It sounds this issue has relating with implementing internal, regional and external agendas including interference in internal affairs by another foreign country, the best example on it, the middle east countries are almost richest countries in some natural resources such as oil, other things but the most people there still live in poverty, illiterate, jobless, live under militaristic and an authoritarian regime, human rights are under threat, lack of freedom of performing religious and social rituals, and other several violations and intervention by the regime under the name of fighting terror or any other names. Although the radicalism is the beginning and earlier stage for the terrorism but neither a person was born as evil nor as terrorism or radical, all human beings were born as same and equal, but there are secondary things, atmosphere which makes a man to think in another way which using violence, being radical is one of them.

Unfortunately nowadays we see there are some states support some extremist groups against other groups inside the country or abroad especially in those countries which the wars or civil war is going on, even it is illegal and terror in the same time makes other parties to think about self-defense which sometimes leading to create armed groups or militia but also using violence in return and no doubt during this 
there will be civil victims on the ground, making displaced people and refugee, causing humanitarian and environmental disaster as well as depriving many people from basic rights, educations and other basic rights. Every issue can be solved in peace way instead of using coercive way because using coercive increasing problems, crisis, making the issue more deeper and then get out of control and all parties will regret for and at the end there is no other choices only sitting together and discus their issues peacefully among themselves and negotiate to compromise and reach at least rid of war.

Now we live in an era of nuclear weapons, where a number of countries possess nuclear weapons, weapons of mass destructions, missile across continents, so that they pose a real threat on international peace and security. In one hand this itself makes and create extremist group and makes a big motivation by some people to think about using violence and terror as well as there is a great fear of transferring the technology to the extremist groups which can have it in any time and use them to have mass destruction, kill innocent people, destroy humanity and spread fear among community.

In another hand some extremist groups have given developed weapons by some states against other states, ethnic, other nationality just to impose their political ideas or to have some personal interests by the high rank officials, even for some of them a small sum of money or interests is more than human lives and no matter if how many people go die or be victims, but when they come on TV and speak they show sympathy, lie to community, help with relief just to trick general opinion but on the ground is totally different and contrary to it, most of us believe what they proclaim, so they use public fund, formal TV and other social media just to personal interests, which create some kind of enmity, make aversion and unwillingness as leads to violence in future. Whereas Media is an important thing in current situation which can reach information, exchange ideas, technologies, learn many good things from it but is used in bad ways by the extremists and terrorist groups as well, some groups have exclusive broadcasting channels to publish their activities, frighten people, show their ability, attract others as well as cultivation of evil and enmity among people by using and exploiting religion, ethnic, color, race, sex or based on other things.

Unfortunately they sometimes broadcast live killing people, destroying buildings and public properties through social media, so these things need to be deprived from broadcasting by the original source and do not let them to publish what extremist groups want not only by them but for others is true who wants the same or to urge violence, terror among society, globalization has its good role which we can know and be familiar with what is going on wherever things happen but almost everything looks like a double edged sword which can be used in both right and wrong ways and media is one of the important thing for the time being and has a big effect on individual in particular and on society in general. Unfortunately sometimes we see some programs, movies, dramas, other visible or invisible things publish by the formal broadcasting networks which funds by the formal government and create extremist groups or at least motivate people to use violence and other coercive ways instead of other peaceful ways. There should be an extensive observation on formal 
and informal broadcasting channels which do not allow them to insult and attack on religion rituals, deface reputation, or any other using which makes bad effect on individual and people that increase violence and terror among people, makes people to think about revenge in case if there is deprivation of basic rights and serves by the majority in society or by the government itself when there are more than a nations and ethnics live in the country. Most of time minority feel they are second degree of citizens inside the country especially in the dictator regime.

\section{References:}

1- The Official site of (UNODC). (2018), Counter Terrorism1-Introduction to International Terrorism, Retrieved from: https://www.unodc.org/documents/e4j/1804932_CT_Mod_01_ebook_FINALpdf.pdf.
2- Anoyn.
(2020).
causes
of terrorism,
Retrieved
from:

https://www.readyscotland.org/media/1316/causesofterrorismfactsheet2_tcm4-716336.pdf.

3- Sroka, A. Garrone, F.and Kumbrián, R. (2020). Radicalism and terrorism in $21^{\text {st }}$ century, Retrieved from:https://www.peterlang.com/view/9783631706381/xhtml/chapter03.xhtml.

4- The official site of U.S Department of Homeland Security. (2016). Global Terrorism Index, Retrieved from: http://economicsandpeace.org/wp-content/uploads/2016/11/Global-TerrorismIndex-2016.2.pdf.

5- The official site of U.S Department of Homeland Security. (2017). Global Terrorism Indexvision of humanity, Retrieved from:http://visionofhumanity.org/app/uploads/2017/11/GlobalTerrorism-Index-2017.pdf.

6- Meierrieks,D. Krieger,T. April (2011), What causes terrorism? Retrieved from: https://www.researchgate.net/publication/258833074_What_causes_terrorism.

7- Borum R. (2004), Psychology of terrorism, Retrieved from: https://www.ncjrs.gov/pdffiles1/nij/grants/208552.pdf.

8- Butler T. What, "n.d." causes terrorism? Retrieved from: https://www.mckendree.edu/academics/scholars/butler-issue-25.pdf.

9- Ta,spınar Ö. (2009). Fighting Radicalism, not 'Terrorism': Root Causes of an International Actor Redefined, Retrieved from: https://www.brookings.edu/wpcontent/uploads/2016/06/summer_fall_radicalism_taspinar.pdf.

10- MORGAN J. M., (2004). The Origins of the New Terrorism, Retrieved from: file:///C:/Users/optimos\%20prime/Downloads/446006.pdf.

11- Jařab, J., May (2005), Media and terrorism, Retrieved from:https://assembly.coe.int/nw/xml/XRef/X2H-Xref-ViewHTML.asp?FileID=10914\&lang=EN. 